\title{
The Effect of Electric Field on Important Food-processing Enzymes: Comparison of Inactivation Kinetics under Conventional and Ohmic Heating
}

\author{
I. CASTRO, B. MACEDO, J.A. TEIXEIRA, AND A.A. ViCENTE
}

\begin{abstract}
This work deals with the determination of the inactivation kinetics of several enzymes, most of them used as time-temperature integrators in the food industry. The tested enzymes were polyphenoloxidase, lipoxygenase, pectinase, alkaline phosphatase, and $\beta$-galactosidase, and the inactivation assays were performed under conventional and ohmic heating conditions. The thermal history of the samples (conventional and ohmically processed) was made equal to determine if there was an additional inactivation caused by the presence of an electric field, thus eliminating temperature as a variable. All the enzymes followed 1st-order inactivation kinetics for both conventional and ohmic heating treatments. The presence of an electric field does not cause an enhanced inactivation to alkaline phosphatase, pectinase, and $\beta$ - galactosidase. However, lipoxygenase and polyphenoloxidase kinetics were significantly affected by the electric field, reducing the time needed for inactivation. The results of the present work can be used industrially to determine processing effectiveness when ohmic heating technology is applied.
\end{abstract}

Keywords: enzyme inactivation, time-temperature integrators, food processing, ohmic heating

\section{Introduction}

$\mathrm{T}$ he increased interest of consumers both for healthy and highquality foods has prompted producers to develop new products and new processing technologies. Ohmic heating (also called Joule heating) is defined as a process where electric currents are passed through foods with the main purpose of heating them. Ohmic heating is distinguished from other electrical heating methods by the presence of electrodes contacting the foods, the frequency, and the waveform of the electric field imposed between the electrodes.

The industrial application of the ohmic heating technology is fully dependent on its validation with experimental data to evaluate the effects of the electric field on microorganisms, enzymes, and biological tissues.

Several enzymes are used in the food industry for improving food quality (for example, texture and flavor), for the recovery of by-products and for achieving higher rates of extraction (Somogyi 1996; Van Loey and others 2002). On the other hand, enzymes may also have negative effects on food quality such as production of offodors and tastes and altering textural properties. Therefore, control of enzymatic activity is required in many food processing steps to promote/inhibit enzymatic activity during processing. Studies on the degradation kinetics of various enzymes were conducted by several authors to determine the effects of pulse electric fields on enzymes' inactivation (Barbosa-Canovas and others 1998; Castro and others 2001; Ho and others 1997; Grahl and Markl 1996). Also, the

MS 20040306 Submitted 5/11/04, Revised 6/24/04, Accepted 7/26/04. Authors are with Centro de Engenharia Biológica, Univ. do Minho, Campus de Gualtar, 4710-057 Braga, Portugal. Direct inquiry to author Vicente (E-mail: avicente@deb.uminho.pt). effects of high hydrostatic pressure processing on enzyme inactivation kinetics were assessed, for example, by Ludikhuyze (1998) and Denys and others (2000).

There is only limited information available concerning the effects of ohmic heating on enzyme activity. This works aims at determining the sensitivity of several food-related enzymes toward ohmic heating. The studied enzymes were lipoxigenase (LOX), pectinase (PEC), polyphenoloxidase (PPO), alkaline phosphatase (ALP), and $\beta$-galactosidase ( $\beta$-GAL).

Garotte and others (2003) evaluated the sensory character of blanched vegetable purées to which isolated enzymes had been added and found that LOX was the enzyme most active in aroma deterioration in English green peas and green beans. LOX is widely distributed in vegetables, and evidence is mounting to support its involvement in off-flavor development and color loss (Garotte and others 2003). To optimize the blanching process of vegetables, it is essential to establish the kinetic model of the inactivation of this indicator enzyme. LOX is also important in the baking industry because it interacts with the gluten side chain, making the gluten more hydrophobic and, subsequently, stronger. With stronger gluten, the dough will have better gas retention properties and increased tolerance to mixing.

PEC hydrolyzes the linkages that hold the small building blocks of galacturonic acid together in the pectic substances, producing smaller molecules. Its main functions in foods are to clarify juices and wines, to reduce viscosity by hydrolyzing the pectin, to accelerate the rate of filtration, to prevent pectin gel formation, and to improve color extraction from grape skin (Somogyi 1996).

The official name of the enzyme responsible for enzymatic browning is ortho-diphenol oxygen oxidoreductase, also known as catecholase, tyrosinase, phenolase, and polyphenol oxidase (Kim 
1995; Somogyi 1996). There are different phenols present in fruits and vegetables at the same time used as substrates for PPO. Browning occurs only when the tissues are disrupted or destroyed and the compounds come into contact with air and with each other. The browning of fruits and vegetables is undesirable, and so these are handled carefully to avoid tissue injury. In some cases, however (for example, cocoa and tea), browning is important to flavor and color development and so the tissues of these plants are deliberately damaged.

Alkaline phosphatase (ALP) is involved in several physiological processes apparently connected to membrane transport phenomenon and is used in biomedical research. In the food industry, ALP is an enzyme used as an indicator of the effectiveness of the milk thermal processing.

People that are lactose-intolerant cannot eat several milk and milk-derived products. When the intestine produces little or no lactase, lactose (the milk sugar) is not digested and moves into the colon, where bacteria ferment it, producing hydrogen, carbon dioxide, and organic acids. The results of this fermentation are diarrhea, flatulence (gas), and abdominal discomfort. The treatment of lactose containing foodstuffs with the enzyme $\beta$-galactosidase $(\beta$ GAL) allows obtaining dairy products that can be consumed by lactose-intolerant individuals.

\section{Materials and Methods}

\section{Heating phase}

Conventional thermal degradation. For each enzyme tested, samples of $0.2 \mathrm{~mL}$ in $2 \mathrm{~mL}$ Eppendorf tubes (9 $\mathrm{mm}$ of internal dia and $40 \mathrm{~mm}$ of height) were placed in a temperature-controlled water bath at the desired temperature, depending on the temperature assay. Samples were taken and placed immediately into ice to stop the thermal degradation effect. The dimensions of the Eppendorf tubes minimize temperature gradients due to heat transfer resistance.

The thermal history of the samples, until temperature stabilization, was monitored by the introduction of a thermocouple connected to the data acquisition system previously described (Castro and others 2004).

Ohmic thermal degradation. The ohmic heater used consisted of a cylindrical glass tube of $30 \mathrm{~cm}$ total length and $2.3 \mathrm{~cm}$ inside dia. Three thermocouple openings were provided: 2 at equal distance of the center of the tube and 1 at the center, where the thermocouple was placed. Two Titanium electrodes with Teflon pressure caps were placed at each top of the tube.

For each enzyme, samples of approximately $25 \mathrm{~mL}$ were heated using an alternating current source of $50 \mathrm{~Hz}$ frequency and variable amplitude. Temperature was continuously monitored using type$\mathrm{K}$ thermocouples, set at the geometrical center of the chamber.

The power source was turned on and the electric field was varied through the use of a thermostat to simulate the conventional thermal history of the samples. An example of comparison of the thermal history of the samples is presented in Figure 1. It is very important to have coincidence in the heating phase of both processes because the objective is to evaluate the nonthermal effects of the ohmic processing, thus the thermal effects should be made equal. Samples were taken and placed immediately into ice to stop the thermal degradation effect.

It should be stressed that the electric field strength used during the holding phase of the experiments is very low (in every case lower than $20 \mathrm{~V} \mathrm{~cm}^{-1}$ ) when compared with the ones used in the heating phase of the samples $\left(50<E<90 \mathrm{~V} \mathrm{~cm}^{-1}\right)$.

Each experiment was conducted in duplicate. For the enzymes tested, the temperature range used matched their different inactivation temperatures.

\section{Modeling}

Thermal process characteristics for enzymatic reactions are described in accordance with kinetic parameters such as decimal reduction times $(D)$, inactivation rate constant $(k)$, z values $(z)$, and activation energies $\left(E_{a}\right)$. The $D$ value is defined as the time required to inactivate $90 \%$ of the original enzyme activity at a given temperature (Eq. 1). An inactivation reaction, which follows 1storder kinetics, has a $D$ value equivalent to $2.303 / k$. The temperature dependence of the $D$ value is given by the $z$ value, which represents the temperature increase required to obtain a 10-fold (1-log cycle) decrease in $D$ value (Eq. 2). For a 1st-order decay process, the $D$ value is equivalent to $\ln (10) / k$. Similar to the $z$ value is the activation energy $\left(E_{a}\right)$, which expresses the temperature dependence of the $k$ value as indicated in the Arrhenius relationship (Eq.3).

$$
\frac{\log C_{A}-\log C_{A o}}{t}=\frac{1}{D}
$$

$$
\frac{\log D_{2}-\log D_{1}}{T_{2}-T_{1}}=\frac{1}{z}
$$

$$
k(t)=k_{0} \exp \left(-\frac{E_{c i}}{R T}\right)
$$

where $C_{A}=$ activity $(\mathrm{U}), C_{A 0}=$ initial activity $(\mathrm{U}), D=$ decimal reduction time (min), $Z=$ temperature sensitivity indicator $\left({ }^{\circ} \mathrm{C}\right), E_{a}=$ activation energy $\left(\mathrm{kJ} \cdot \mathrm{mol}^{-1}\right), k=$ frequency constant $\left(\mathrm{s}^{-1}\right)$, and $k_{0}=$ pre-exponential factor $\left(\mathrm{s}^{-1}\right)$. The kinetic parameters $\left(D, z, E_{a}\right.$, and $\left.K\right)$ were calculated for all the experiments conducted.

\section{Enzyme activity measurements}

LOX. LOX type IB from soybeans was purchased as a lyophilized powder, (Sigma L7395, Germany) and was dissolved, without further purification, in Tris $\mathrm{HCl}$ buffer $(0.01 \mathrm{M}$; pH 9). One unit of enzyme causes an increase in the absorption at $234 \mathrm{~nm}$ of $0.001 / \mathrm{min}$ at pH 9 and $25^{\circ} \mathrm{C}$ when linoleic acid is used as substrate. Such unit is equivalent to the oxidation of $0.12 \mu \mathrm{mol}$ of linoleic acid (Kruger and others 1991). The absorption at $234 \mathrm{~nm}$ was recorded during 3

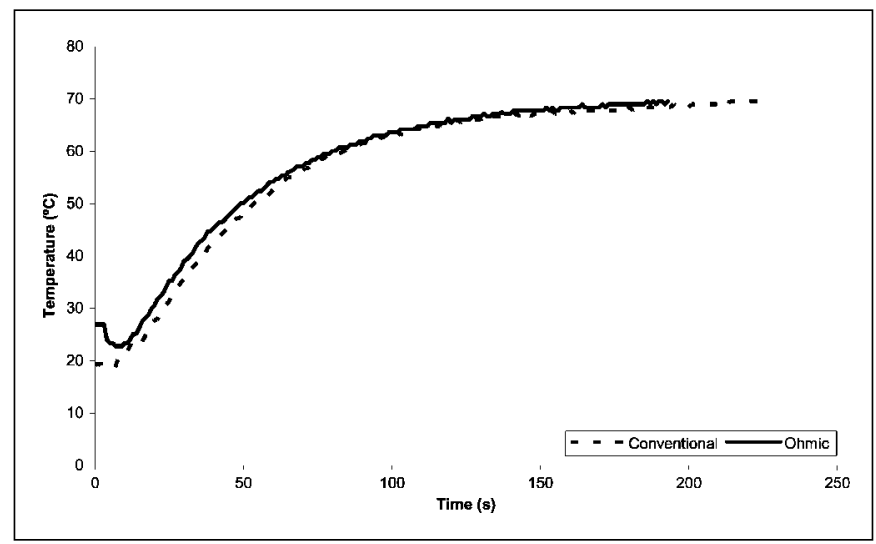

Figure 1-Example of a conventional and ohmic heating profile

Vol. 69, Nr. 9, 2004-JOURNAL OF FOOD SCIENCE C697 
Enzyme inactivation by ohmic heating . . .

Table 1-Overview of enzymatic systems tested, media used, and activity measuring methods

\begin{tabular}{|c|c|c|c|}
\hline Enzyme & Origin & Medium & Activity assay \\
\hline Lipoxygenase (LOX) & Soybean (Sigma) & Tris $\mathrm{HCl}$ buffer $(\mathrm{pH} 9)$ & $\begin{array}{l}\text { Spectrophotometric at } 234 \mathrm{~nm} \text { and } 25^{\circ} \mathrm{C} \text {; } \\
\text { Substrate: linoleic acid }\end{array}$ \\
\hline Polyphenoloxidase (PPO) & Apples (cv. Golden delicious) & Phosphate buffer (pH 6) & $\begin{array}{l}\text { Spectrophotometric at } 395 \mathrm{~nm} \text { and } 30^{\circ} \mathrm{C} \text {; } \\
\text { Substrate: catechol }\end{array}$ \\
\hline Pectinase (PEC) & Fermentation (Novo enzymes) & Citrate buffer ( $\mathrm{pH} 4.5)$ & $\begin{array}{l}\text { Spectrophotometric at } 276 \mathrm{~nm} \text { and } 40{ }^{\circ} \mathrm{C} \text {; } \\
\text { Substrate: polygalacturonic acid }\end{array}$ \\
\hline Alkaline phosphatase (ALP) & Raw milk & Milk & $\begin{array}{l}\text { Spectrophotometric at } 410 \mathrm{~nm} \text { and } 37^{\circ} \mathrm{C} \text {; } \\
\text { Substrate: p-Nitrophenylphosphate }\end{array}$ \\
\hline
\end{tabular}

Table 2-Kinetic parameters of thermal degradation of LOX

\begin{tabular}{|c|c|c|c|c|c|c|c|}
\hline & \multicolumn{7}{|c|}{ Temperature $\left({ }^{\circ} \mathrm{C}\right)$} \\
\hline & 60 & 62 & 65 & 68 & 70 & 75 & 78 \\
\hline $\begin{array}{l}D_{\text {conventional }}(\mathrm{min}) \\
D_{\text {ohmic }}(\mathrm{min}) \\
z_{\text {conventional }}\left({ }^{\circ} \mathrm{C}\right) \\
z_{\text {ohmic }}\left({ }^{\circ} \mathrm{C}\right) \\
k_{0 \_ \text {conventional }}\left(\mathrm{s}^{-1}\right) \\
k_{0} \text { ohmic }\left(\mathrm{s}^{-1}\right) \\
E_{\text {a_conventional }}\left(\mathrm{J} \cdot \mathrm{mol}^{-1}\right) \\
E_{\text {a ohmic }}\left(\mathrm{J} \mathrm{mol}^{-1}\right)\end{array}$ & $\begin{array}{l}117.8 \\
6.92 \\
11.102\left(r^{2}=0.99\right) \\
15.042\left(r^{2}=0.98\right) \\
0.9971\left(r^{2}=0.99\right) \\
0.9971\left(r^{2}=0.99\right) \\
0.7574 \times 10^{-3} \\
0.9686 \times 10^{-3}\end{array}$ & $\begin{array}{r}20.44 \\
5.38\end{array}$ & $\begin{array}{l}10.03 \\
-\end{array}$ & $\begin{array}{l}5.43 \\
1.57\end{array}$ & $\begin{array}{l}3.76 \\
-\end{array}$ & $\begin{array}{l}0.99 \\
0.58\end{array}$ & $\begin{array}{l}0.77 \\
0.47\end{array}$ \\
\hline
\end{tabular}

min, and the activity was determined from the slope of the linear zone of the curve.

PEC. PEC (Novo Enzymes) activity was determined spectrophotometrically at $276 \mathrm{~nm}$ and $40{ }^{\circ} \mathrm{C}$, using polygalacturonic acid (citrate buffer $\mathrm{pH} 4.5$ ) as substrate. One unit is equivalent to the oxidation of $0.1 \mu \mathrm{mol}$ of polygalacturonic acid. The activity was determined from the slope of the curve during $20 \mathrm{~min}$ (Honda and others 1982).

PPO. PPO was extracted from apples (cv Golden delicious). Apples were blended with a solution of phosphate buffer ( $\mathrm{pH} 7$ ) containing $1 \%(\mathrm{w} / \mathrm{v})$ polyvinylpirrolidine. The mixture was filtered and the liquid extract was recovered. The extract was then centrifuged for $10 \mathrm{~min}$ at $10000 \mathrm{rpm}$ at $4{ }^{\circ} \mathrm{C}$. The activity was determined spectrophotometrically at $395 \mathrm{~nm}\left(30^{\circ} \mathrm{C}\right)$ using catechol (in phosphate buffer, $\mathrm{pH}$ 6) as the substrate (Robinson 1991).

ALP. The determination of ALP activity was performed directly in milk. The activity was expressed in terms of nmol of p-nitrophenilphosphate (pNPP)/mL per minute. The activity was measured as the release of $\mathrm{p}$-nitrophenil (pNP) from pNPP. Samples were incubated with $47 \mathrm{mg}$ pNPP/ $25 \mathrm{~mL}$ Tris buffer, $\mathrm{pH} 10.4$ at $37^{\circ} \mathrm{C}$. The reaction was stopped with $0.02 \mathrm{M} \mathrm{NaOH}$, and the activity was measured spectrophotometrically at $410 \mathrm{~nm}$ (Williams and Nottingham 1990).

$\boldsymbol{\beta}$-GAL. $\beta$-GAL was obtained by fermentation of lactose by a genetically modified strain of Saccharomyces cerevisiae, containing a plasmid carrying the $\beta$-GAL gene of Aspergillus niger (Domingues and others 2000). It is an extracellular enzyme, and therefore it was used without further purification. One unit of activity was defined as the amount of enzyme that hydrolyses $1 \mathrm{nmol} \mathrm{p}$-nitrophenil $\beta$ D-galactopyranoside (pNPG)/min at $65^{\circ} \mathrm{C}$. The activity was measured as the amount of p-nitrophenol released from pNPG per minute. Samples were incubated with $1.7 \mathrm{mM}$ substrate in $0.075 \mathrm{M}$ $\mathrm{Na}$-acetate buffer, $\mathrm{pH} 4.5$. The $\mathrm{pH}$ was raised to 10 with $1 \mathrm{M}$ of $\mathrm{Na}_{2} \mathrm{CO}_{3}$ and the activity was measured spectrophotometrically at $405 \mathrm{~nm}$ (Bailey and Linko 1990). Table 1 summarizes the origin and the methods for activity determination of the enzymes studied.

\section{Statistical analysis}

To evaluate whether the differences found in the kinetic parameters determined under conventional and ohmic heating treatments were significant or not, two-way analysis of variance was performed at a significance level of 5\%. The results of this analysis were expressed in terms of the probability of the samples being equal (if lower than $5 \%$, they were considered different).

\section{Results and Discussion}

E nzyme denaturation is caused by rearrangement and/or destruction of noncovalent bonds such as hydrogen bonds, hydrophobic interactions, and ionic bonds of the tertiary protein structure. The presence of an electric field can influence biochemical reactions by changing molecular spacing and increasing interchain reactions. In this study, the temperature as a variable was eliminated by simulating the conventional heating profile during the ohmic heating phase (see Figure 1); as so, the possible differences in the results obtained must be related to the effect of an electric field.

The thermal inactivation profiles (of both conventional and ohmic heating) followed 1st-order kinetics for all tested enzymes. This can be concluded from the results presented in Table 2 to 6 and also from Figure 2 to 6 . It should be noted that the linear regression coefficients were in all cases very close to 1 .

Lipoxygenases (LOX) are nonheme but iron-containing dioxygenases that catalyze the dioxygenation of polyunsaturated fatty acids containing a cis,cis-1,4-pentadiene-conjugated double bond system such as linoleate and linolenate to yield hydroperoxides. Table 2 presents the kinetic parameters obtained for the thermal degradation of LOX. The obtained results show that the electric field has an additional effect on the LOX inactivation with approximately 5 times lower $D$ values (Figure 2). The results of analysis of variance show that the differences found were significant at a $95 \%$ significance level in terms of $D$ values $(P<0.05$, in all cases; results not shown) as well as in for $z$ values ( $P=0.047$, see Table 7$)$. This means that for the same inactivation degree, the time required for 
Table 3-Kinetic parameters of thermal degradation of PEC.

\begin{tabular}{|c|c|c|c|c|c|c|}
\hline & \multicolumn{6}{|c|}{ Temperature $\left({ }^{\circ} \mathrm{C}\right)$} \\
\hline & 60 & 62 & 65 & 68 & 70 & 75 \\
\hline $\begin{array}{l}D_{\text {conventional }}(\mathrm{min}) \\
D_{\text {ohmic }}(\mathrm{min}) \\
z_{\text {conventional }}\left({ }^{\circ} \mathrm{C}\right) \\
z_{\text {ohmic }}\left({ }^{\circ} \mathrm{C}\right) \\
k_{0 \_ \text {conventional }}\left(\mathrm{s}^{-1}\right) \\
k_{0 \_ \text {ohmic }}\left(\mathrm{s}^{-1}\right) \\
E_{\text {a_conventional }}^{\text {a }}\left(\mathrm{J} \mathrm{mol}^{-1}\right) \\
E_{\text {a_ohmic }}\left(\mathrm{J} \mathrm{mol}^{-1}\right)\end{array}$ & $\begin{array}{l}14.00 \\
15.00 \\
8.12\left(r^{2}=0.99\right) \\
7.72\left(r^{2}=0.99\right) \\
0.997\left(r^{2}=0.96\right) \\
0.997\left(r^{2}=0.99\right) \\
0.782 \times 10^{-3} \\
0.560 \times 10^{-3}\end{array}$ & $\begin{array}{l}9.79 \\
8.70\end{array}$ & $\begin{array}{l}3.41 \\
3.57\end{array}$ & $\begin{array}{l}1.56 \\
1.67\end{array}$ & $\begin{array}{l}0.75 \\
0.83\end{array}$ & $\overline{0.52}$ \\
\hline
\end{tabular}

thermal treatment (for example, blanching of vegetables) is much lower (Figure 2) when an ohmic heating process is applied, thus reducing negative thermal effects in the other food components.

The hypothesis of the additional effect of the electric field being due to the separation of the subunits or breakage of the enzyme molecule was raised. This hypothesis was checked by polyacrylamide gel electrophoresis (PAGE) (data not shown). When the PAGE system is run with proteins under their native form (native PAGE), these proteins move through the gel when an electric field is applied and each band on the gel represents a different protein (or a protein sub-unit). If there was a sub-unit separation due to heating, different bands would appear in the gel, corresponding to different subunits. Nevertheless, both the nontreated enzyme and the heat-treated enzyme (in this latter case, enzymes used were both conventionally and ohmically treated) presented the same number and position of bands in the gel, leading to the conclusion that before and after the thermal treatments (conventional or ohmic) the enzyme had the same molecular weight and no sub-unit separation occurred.

The same PAGE can be performed when proteins are previously treated with sodium dodecyl sulphate (SDS-PAGE). SDS is an anionic detergent, which denatures proteins and induces a negative charge cloud on the surface of the denatured molecules, so that they acquire equal charge densities per unit length. This makes them migrate through the gel according to their molecular weight and was used to determine the protein's size. Also, in this electrophoresis, both proteins (conventionally or ohmic heated) had the same profile on the gel. Despite these efforts, the effect of ohmic heating in the structure of proteins needs further assessment.

The kinetic parameters for PEC inactivation are presented in Table 3, where, together with Figure 3, it is clear that the electric field

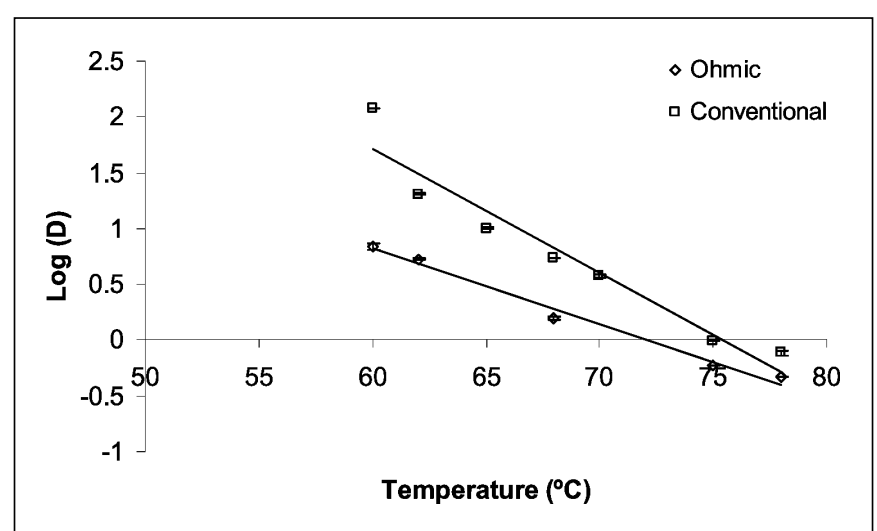

Figure 2-Degradation kinetics of LOX when submitted to conventional or ohmic heating does not have any influence in the inactivation kinetic parameters. The results of the analysis of variance test show that, for both conventional and ohmic processing, $D$ and $z$ values can be considered identical $(P>0.05)$. PEC has no prosthetic group (Table 7$)$ and the hypothesis that relates the loss of activity to the loss of the metallic prosthetic group caused by the electric field is in agreement with the data obtained for this enzyme. However, once again, this needs further clarification. The color extraction from grapes is improved by the use of pectinases and also by the increase of temperature (Somogyi 1996). Ohmic heating has been reported to enhance beet dye extraction (de Alwis and Fryer 1990) and to improve apple juice yield (Lima and Sastry 1999). The use of ohmic heating to increase the temperature, during the color extraction phase of a vinification process, may be an interesting industrial application of this technology, and these results show clearly that it can be applied together with pectinases once their activity is not affected by the electric field.

The effects of the electric field on the thermal inactivation kinetics of PPO (Table 4, Figure 2) are similar to the ones described for LOX. Enhanced enzyme inactivation is obtained when an electric field is present, thus reducing inactivation time. Statistical significant differences were found between $z$ values $(P=0.02$, see Table 7). Plant PPOs are nuclear-encoded copper metalloproteins having a molecular mass of approximately $59 \mathrm{kDa}$. These results are encouraging to use ohmic heating in blanching of fruits, for example, once to obtain the same level of PPO inactivation, a less aggressive thermal treatment is needed. Consequently, the thermal destruction of nutrients (for example, vitamins and pigments) and fruit

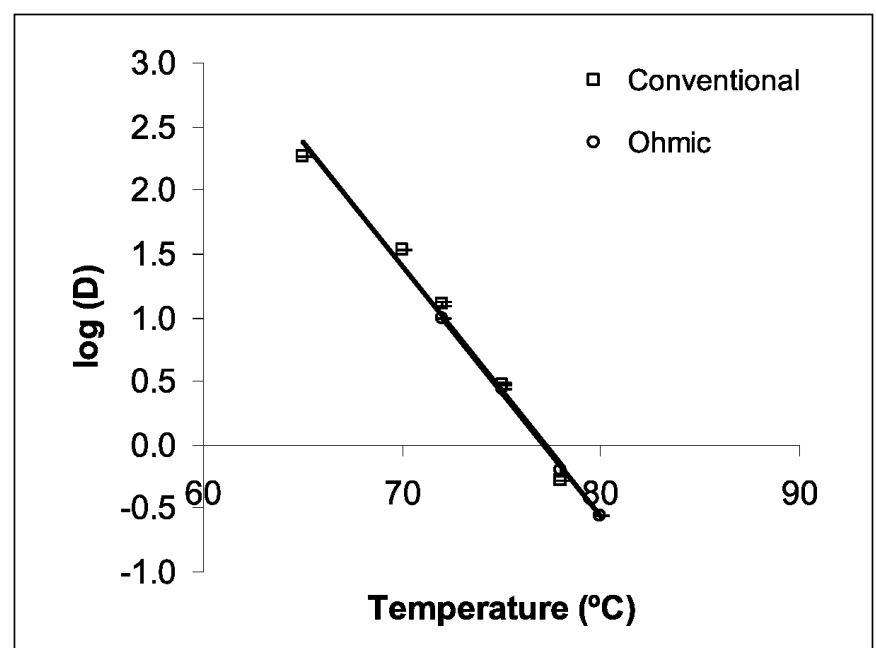

Figure 3-Degradation kinetics of PEC when submitted to conventional or ohmic heating 
Table 4-Kinetic parameters of thermal degradation of PPO.

\begin{tabular}{|c|c|c|c|c|c|c|}
\hline & \multicolumn{6}{|c|}{ Temperature $\left({ }^{\circ} \mathrm{C}\right)$} \\
\hline & 70 & 75 & 80 & 85 & 90 & 95 \\
\hline $\begin{array}{l}D_{\text {conventional }}(\mathrm{min}) \\
D_{\text {ohmic }}(\mathrm{min}) \\
Z_{\text {conventional }}\left({ }^{\circ} \mathrm{C}\right) \\
Z_{\text {ohmic }}\left({ }^{\circ} \mathrm{C}\right) \\
k_{0 \_ \text {conventional }}\left(\mathrm{s}^{-1}\right) \\
k_{0} \text { ohmic } \\
E_{\text {a_conventional }}\left(\mathrm{S} \mathrm{mol}^{-1}\right) \\
E_{a \text { ohmic }}\left(\mathrm{J} \mathrm{mol}^{-1}\right)\end{array}$ & $\begin{array}{l}193.0 \\
\overline{1} \\
12.20\left(r^{2}=0.99\right) \\
12.97\left(r^{2}=0.98\right) \\
0.997\left(r^{2}=0.99\right) \\
0.997\left(r^{2}=0.98\right) \\
0.777 \times 10^{-3} \\
0.815 \times 10^{-3}\end{array}$ & $\begin{array}{l}61.61 \\
19.37\end{array}$ & $\begin{array}{r}23.74 \\
6.79\end{array}$ & $\begin{array}{r}10.30 \\
3.52\end{array}$ & $\begin{array}{l}3.15 \\
0.92\end{array}$ & $\begin{array}{l}1.51 \\
0.58\end{array}$ \\
\hline
\end{tabular}

Table 5-Kinetic parameters of thermal degradation of ALP

\begin{tabular}{|c|c|c|c|c|c|c|}
\hline & \multicolumn{6}{|c|}{ Temperature $\left({ }^{\circ} \mathrm{C}\right)$} \\
\hline $\begin{array}{l}D_{\text {conventional }}(\mathrm{min}) \\
D_{\text {ohmic }}(\mathrm{min}) \\
Z_{\text {conventional }}\left({ }^{\circ} \mathrm{C}\right) \\
Z_{\text {ohmic }}\left({ }^{\circ} \mathrm{C}\right) \\
k_{0} \\
k_{0 \_ \text {conventional }}\left(\mathrm{s}^{-1}\right) \\
E_{a \text { _conventional }}\left(\mathrm{J} \mathrm{mol}^{-1}\right) \\
E_{a \text { onmic }}\left(\mathrm{J} \mathrm{mol}^{-1}\right)\end{array}$ & $\begin{array}{l}35.46 \\
31.75 \\
9.05\left(r^{2}=0.98\right) \\
9.30\left(r^{2}=0.99\right) \\
0.997\left(r^{2}=0.99\right) \\
0.997\left(r^{2}=0.99\right) \\
0.649 \times 10^{-3} \\
0.675 \times 10^{-3}\end{array}$ & $\begin{array}{l}19.00 \\
11.00\end{array}$ & $\begin{array}{l}4.41 \\
4.06\end{array}$ & $\begin{array}{l}3.54 \\
2.89\end{array}$ & $\begin{array}{l}1.96 \\
1.28\end{array}$ & $\begin{array}{l}0.91 \\
0.89\end{array}$ \\
\hline
\end{tabular}

texture (a quality parameter) will be obviously lower, thus increasing the final quality of the products, as reported elsewhere.

For ALP, both conventional and ohmic inactivation mechanisms are similar (Table 5, Figure 5), and the results of the $z$ values obtained do not show a clear additional effect of the electric field on the enzyme inactivation $(P>0.05$, see Table 7$)$. However, for lower temperatures, $D$ values are significantly different $(P<0.05$, data not shown). This result may suggest that the continuous application of an electric field may have a delayed effect on this enzyme at lower temperatures, but the long-term effects of the exposure to a continuous electric field are out of the scope of this work. Considering that milk thermal processing effectiveness in determined by this enzyme, the results indicate that even if milk is ohmically pasteurized, this enzyme may continue to be used as a time-temperature indicator (TTI) by the dairy industry. In fact, if there was activity loss caused by the presence of the electric field, the risk of accepting under-processed milk was high, thus affecting food safety.

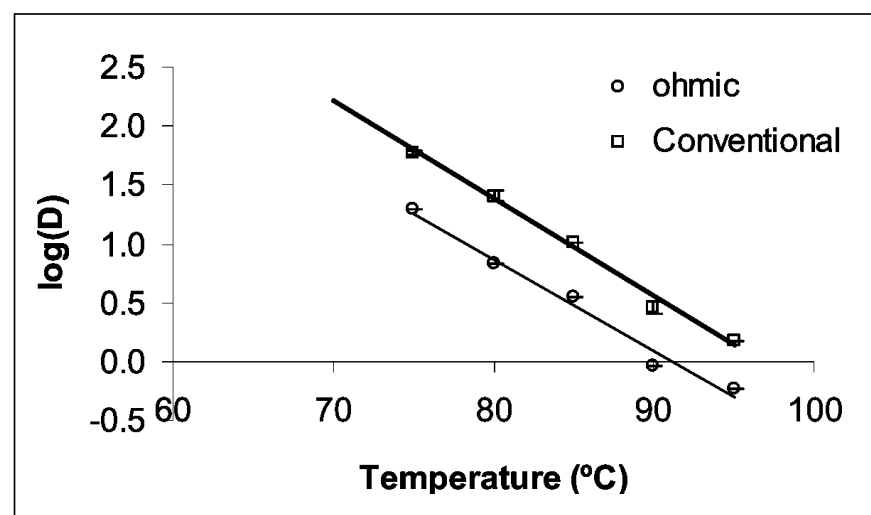

Figure 4-Degradation kinetics of PPO when submitted to conventional or ohmic heating
For $\beta$-GAL, as already reported for ALP and PEC, both conventional and ohmic inactivation mechanisms are similar (Table 6, Figure 6), and the results obtained do not show a clear additional effect of the electric field on the enzyme inactivation $(P>0.05$, see Table 7$)$.

The obtained results suggest that the use of ohmic heating in an industrial process application will clearly improve the final quality of products once the thermal treatment is less aggressive: uniform heating will minimize the overprocessed areas; the nutrients such as ascorbic acid will not be affected by the presence of the electric field (Castro and others 2004), important enzymes (for example, PEC, $\beta$-GAL) will not have enhanced inactivation kinetics, and the enzymes supposed to be inactivated will be easily destroyed.

The presence of the electric field may remove the metallic prosthetic groups present of the enzymes LOX and PPO (Table 7), thus causing the enhancement of activity loss. However, this hypothesis needs to be verified, which is out of the scope of the present work.

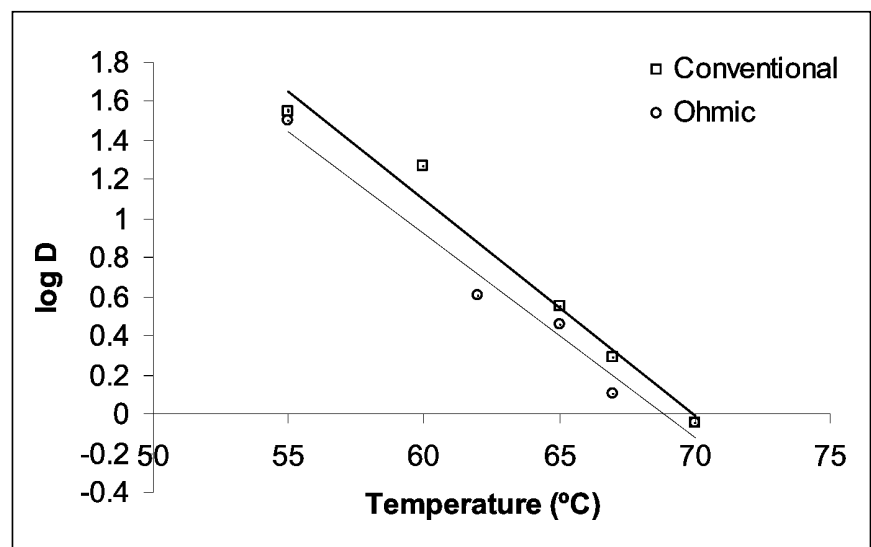

Figure 5-Degradation kinetics of ALP when submitted to conventional or ohmic heating 
Table 6-Kinetic parameters of thermal degradation of $\beta$-GAL

\begin{tabular}{|c|c|c|c|c|c|c|}
\hline & \multicolumn{6}{|c|}{ Temperature $\left({ }^{\circ} \mathrm{C}\right)$} \\
\hline & 65 & 70 & 72 & 75 & 78 & 80 \\
\hline $\begin{array}{l}D_{\text {conventional }}(\mathrm{min}) \\
D_{\text {ohmic }}(\min ) \\
z_{\text {conventional }}\left({ }^{\circ} \mathrm{C}\right) \\
z_{\text {ohmic }}\left({ }^{\circ} \mathrm{C}\right) \\
k_{0 \_ \text {conventional }}\left(\mathrm{s}^{-1}\right) \\
k_{0 \_ \text {ohmic }}\left(\mathrm{s}^{-1}\right) \\
E_{\text {a_conventional }}\left(\mathrm{J} \mathrm{mol}^{-1}\right) \\
E_{a \text { ohmic }}\left(\mathrm{J} \mathrm{mol}^{-1}\right)\end{array}$ & $\begin{array}{l}182.0 \\
- \\
5.12\left(r^{2}=0.99\right) \\
5.08\left(r^{2}=0.98\right) \\
0.997\left(r^{2}=0.98\right) \\
0.997\left(r^{2}=0.98\right) \\
0.370 \times 10^{-3} \\
0.350 \times 10^{-3}\end{array}$ & $\begin{array}{l}33.90 \\
-\end{array}$ & $\begin{array}{r}12.89 \\
9.70\end{array}$ & $\begin{array}{l}2.99 \\
2.77\end{array}$ & $\begin{array}{l}0.52 \\
0.64\end{array}$ & $\begin{array}{l}0.50 \\
0.28\end{array}$ \\
\hline
\end{tabular}

\section{Conclusions}

$\mathrm{T}$ The effect of the electrical field on enzymes has to be assessed before ohmic heating technology is fully implanted for the continuous processing of foods. The obtained data, using target enzymes from different sectors of the food industry, show that the use of ohmic heating as an alternative to conventional heating is beneficial in terms of enzyme inactivation when that is the main purpose (cases of LOX and PPO) because the electric field reduces the $D$ values for those enzymes when compared with conventional heating. The activity of PEC, ALP, and $\beta$-GAL does not seem to be more affected by ohmic heating than by conventional heating. This result is quite encouraging because PEC and $\beta$-GAL are process enzymes that should not be inactivated. On the other hand, the use of ohmic heating technology implies that process effectiveness criteria (TTIs such as enzymes and target microorganisms) must be validated. The kinetic parameters obtained show that ALP may continue to be used as a TTI, in the dairy industry, without further adaptations. On the contrary, for PPO and LOX the traditionally used inactivation kinetics will have to be replaced by the ones obtained in the present work, if ohmic heating technology is to be applied. The effect of ohmic heating on enzymes structure needs to be further assessed.

\section{References}

Bailey M, Linko M. 1990. Production of B-galactosidase by Aspergillus oryzae in submerged biorector cultivation. J Biotechnol 16:57-66.

Barbosa-Cánovas GV, Pothakamury UR, Palou E, Swanson BG. 1998. Biological effects and applications of pulsed electric fields for the preservation of foods. In: Barbosa-Cánovas GV, Pothakamury UR, Palou E, Swanson BG, editors.

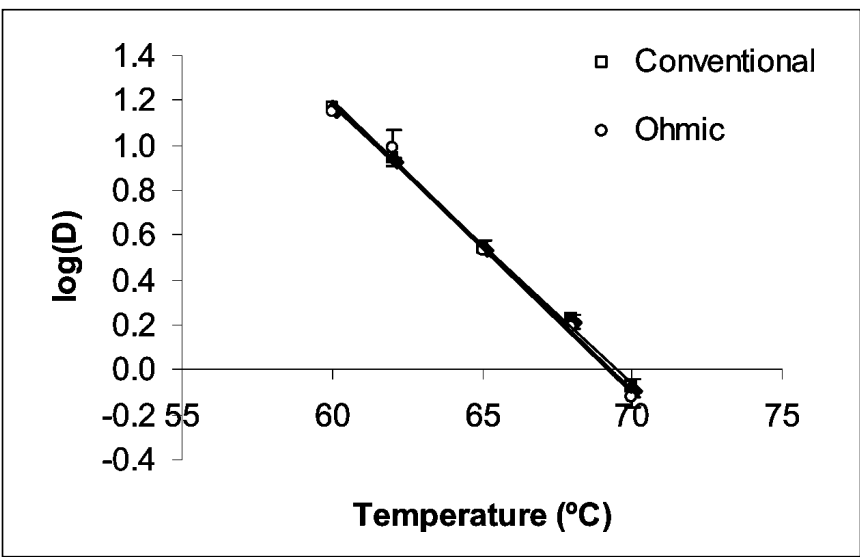

Figure 6-Degradation kinetics of $\beta$-Gal when submitted to conventional or ohmic heating
Table 7-Least significance difference test for $z$ values ( \pm standard deviation) determined under ohmic and conventional heating conditions for all the enzymes tested

\begin{tabular}{llccl}
\hline Enzyme & $\begin{array}{c}\text { Prosthetic } \\
\text { group }\end{array}$ & $\boldsymbol{z}_{\text {conventional }}$ & $\boldsymbol{z}_{\text {ohmic }}$ & $\boldsymbol{P}$ \\
\hline LOX & $\mathrm{Fe}$ & $11.102 \pm 0.34$ & $15.042 \pm 0.38$ & 0.047 \\
PEC & - & $8.12 \pm 0.21$ & $7.72 \pm 0.34$ & 0.075 \\
PPO & $\mathrm{Cu}$ & $12.20 \pm 0.08$ & $12.80 \pm 0.04$ & 0.02 \\
ALP & $\mathrm{Zn}, \mathrm{Mg}$ & $9.05 \pm 0.127$ & $9.30 \pm 0.05$ & 0.145 \\
$\beta-G A L$ & - & $5.12 \pm 0.08$ & $5.08 \pm 0.17$ & 0.437 \\
\hline
\end{tabular}

Nonthermal preservation of foods. New York: Marcel Dekker.

Castro AJ, Swanson BG, Barbosa-Cánovas GV, Meyer R. 2001. Pulsed electric field modification of milk alkaline phosphatase activity. In: Barbosa-Cánovas GV, Zhang QH, editors. Pulsed electric fields in food processing: Fundamental aspects and applications (Vol. 3). Lancaster, Pa: Technomic Publishing Co. p 65-83.

Castro I, Teixeira JA, Salengke S, Sastry SK, Vicente AA. 2004. Ohmic heating of strawberry products: electrical conductivity measurements and degradation kinetics. Inn Food Sci Emerg Technol 5:27-36.

De Alwis AAP, Fryer PJ. 1990. The use of network theory in the finite-element analysis of coupled thermo-electric fields. Comput Appl Num Meth 6:61-66.

Denys S, Van Loey AM, Hendrickx ME. 2000. A modeling approach for evaluating process uniformity during batch high hydrostatic pressure processing: combination of a numerical heat transfer model and enzyme inactivation kinetics. Inn Food Sci Emerg Technol 1:5-19.

Domingues L, Vicente AA, Lima N, Teixeira JA. 2000. Applications of yeast flocculation in biotechnological processes. Biotech Biop Eng 5:288-305.

Garotte RL, Silva ER, Bertone RA. 2003. Kinetic parameters for thermal inactivation of cut green beans lipoxygenase using unsteady-state methods. Latin Amer Appl Res 33:87-90.

Grahl T, Markl H. 1996. Killing of microorganisms by pulsed electric fields. Appl Microbiol Biotechnol 45:148-57.

Ho SY, Mittal GS, Cross JD. 1997. Effects of high field electric pulses on the activity of selected enzymes. J Food Eng 31:69-84.

Honda S, Nishimura Y, Takahashi M, Chiba H, Kakehi K. 1982. Anal Biochem 119:194-203.

Kim L, Hwang MS, Kim ES. 1995. Extraction, partial characterization, and inhibition patterns of polyphenol oxidase from burdock (Arctium lappa). In: Y Lee C, Whitaker JR, editors. Enzymatic browning and its prevention. Washington, D.C.: American Chemical Society Symposium Series 600.

Kruger JE, MacGregor AW, Marchylo B. 1991. Endogenous cereal enzymes. In: Fox PF, editor. Food enzymology, vol. 2, chapter 17. London and New York: Elsevier Applied Science. p 1-46.

Lima M, Sastry SK. 1999. The effects of ohmic heating frequency on hot-air drying rate and juice yield. J Food Sci 41:115-9.

Ludikhuyze L. 1998. High pressure technology in food processing and preservation: a kinetic case study on the combined effect of pressure and temperature on enzymes [ $\mathrm{PhD}$ dissertation]. Leuven, Belgium: Katholieke Univ. Leuven. p 46-97. Available from: Library of the Katolieke Univ. Leuvan, Belgium.

Robinson DS. 1991. Peroxidases and their significance in fruits and vegetables. In: Fox PF, ed. Food enzymology, vol. 1, chapter 10. London and New York: Elsevier Applied Sci. p 399-426.

Somogyi LP, Ramaswamy HS, Hui YH. 1996. Biology, principles and applications In: Processing fruits: science and technology, vol. 1. Lancaster, Pa.: Technomic Publishing Co. Inc. p 95-113, 237-9.

Van Loey A, Verachtert B, Hendrickx M. 2002. Effects of high electric field pulses on enzymes. Trends Food Sci Technol 12:94-102.

Williams DJ, Nottingham SM. 1990. Suitability of a modification to the Aschattenburg and Mullen alkaline phosphatase test for goat's milk: collaborative study. Aust J Dairy Technol 45(1):21-3. 